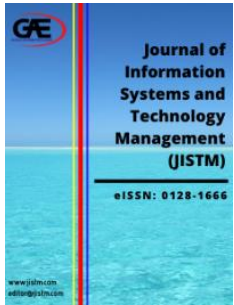

JOURNAL OF INFORMATION

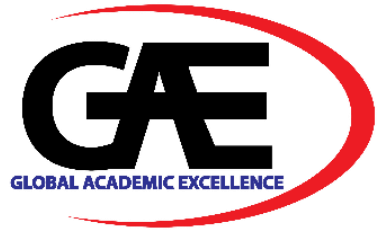

\title{
THE IMPACT OF INDUSTRY REVOLUTION 4.0 TOWARDS THE READINESS OF EMPLOYEE IN MANUFACTURING SECTOR IN JOHOR BAHRU, MALAYSIA
}

\author{
Mohd Khairulnizam Zahari ${ }^{*}$, Wan Norsyafawati W. Muhamad Radzi ${ }^{2}$
}

1 Faculty of Applied and Human Sciences, University of Malaysia Perlis, Perlis, Malaysia

Email: nizamzahari@unimap.edu.my

2 Faculty of Applied and Human Sciences, University of Malaysia Perlis, Perlis, Malaysia

Email: norsyafawati@unimap.edu.my

Corresponding Author

\section{Article Info:}

\section{Article history:}

Received date: 15.09 .2021

Revised date: 15.10 .2021

Accepted date: 18.11.2021

Published date: 01.12.2021

\section{To cite this document:}

Zahari, M. K., \& Radzi, W. N. W. M. (2021). The Impact of Industry Revolution 4.0 Towards The Readiness of Employee in Manufacturing Sector in Johor Bahru, Malaysia. Journal of Information System and Technology Management, 6 (24), 27-33.

DOI: $10.35631 / J I S T M .624004$

This work is licensed under CC BY 4.0 (c) (2)

\section{Abstract:}

Industry Revolution 4.0 is an important upcoming concept for our current manufacturing industry. Industry Revolution 4.0 (IR4.0) can change the manufacturing industry to the next level and also enhance the image of the country. The purpose of this research is to study the readiness of the employees towards the implementation of IR4.0 in manufacturing industries in Johor Bahru, Malaysia. The objective of the research is how the technology, changes in consumers' behaviour and environment, and employee performance effect the readiness of employees in the manufacturing sector to implement IR4.0. The current problems are facing by Malaysia are the dependability of foreign labours for production in manufacturing industries and Malaysian manufacturing growth still stuck in Industry 2.0. This research is a quantitative method and used questionnaires to collect data. Total 333 questionnaires were distributed to manufacturing companies in Johor Bahru. Based on the regression analysis result, the relationship between the changes in consumers' behaviour and environment and employee performance is compatible with the readiness of employees in implementing IR4.0. However, the relationship between technology and the dependent variable was less compatible. Therefore, our country should enhance the usage and level of technology to implement IR4.0 to enhance the readiness of employees in the manufacturing industry.

Keywords:

Industry Revolution 4.0, Manufacturing, IR 4.0 


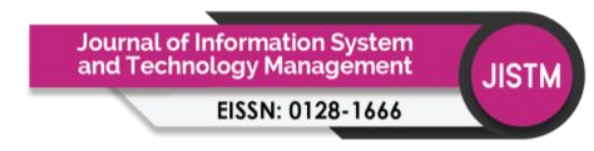

Volume 6 Issue 24 (December 2021) PP. 27-33 DOI: 10.35631/JISTM.624004

\section{Introduction}

With the world's population expected to reach 7.6 billion by 2020 , current technological breakthroughs forecast 50 billion electronic gadgets will interact with one another. This illustrates that the number of communicating devices outnumbers the human population, with an average of 6.58 electronic devices per person (Zaslavsky and Jayaraman, 2015). This data and information-generating networked gadget is connected to the internet. The introduction of a new wave of technology known as "Industry 4.0" and the period of "Digital Economy" or "Digital Economy" has pushed the government to pursue success in the Digital Malaysia Policy. In 2016 the Fourth Industrial Revolution (Industry 4.0) was the third version of the continuation of automation as well as the internet and other physical processes and a cyberphysical system emerged. Industry 4.0 encompasses automation, big data analysis, system integration, clouds, robotics, the Internet of Things (IoT), and other technologies. It entails the use of automation technology to present new challenges to all sectors in the country, requiring them to make changes in accordance with the digital transformation in order to remain competitive and accelerate the development of the modern world landscape (Rojko, 2017). The rise of cyber physical systems is heralded by this transformation, meaning a completely new level of capability for humans, robots, and new technology technologies. To put it another way, automation technology is considered as a technological capability that does not always necessitate human engagement (Muhuri et al., 2019).

Malaysia, which is still heavily reliant on foreign labour for production, needs to change its mindset in order to embrace new technology in order to increase efficiency and productivity and to expand markets through digital platforms (Low et al., 2017). Malaysia may have the head start especially in our electronics, automotive and construction industries to enhance modern manufacturing technologies towards industry 4.0. This phrase illustrate that it can be overcome by Industry 4.0. Malaysia currently in Industry 2.0 and our neighborhood country which are Thailand and Philippines are heading to Industry 4.0 from Industry 3.0. This tells that our country's manufacturing sector need improvement to better production (Gobind Singh, 2019). The workers should be up skilled or trained to be multi-skilled to meet requirements under the increasing digitalization of workplaces (Idris, 2019).

\section{Literature Review}

\section{Dependent variable: Employee Readiness}

This study investigates the effect of three independent variables which are the technology, changes in consumers' behaviour and environment and employee performance towards the readiness of employee in implementing IR4.0 in manufacturing companies in Johor Bahru. Readiness is the state of fully prepared for something and able to adapt with a change. The concept of readiness of employee in implementing Industry 4.0 is the mindset of an employee towards the change of new system which is Industry 4.0. Individual readiness may include selfefficacy, the belief that one will be able to successfully undertake change, or fear of the consequences of change (Howley, 2012). Readiness of employee can be measured using several ways such as perception towards a change, understanding/acceptance towards the change and the involvement of an employee (Holt et al., 2009). The readiness of employee shows the behaviour and thought towards Industry 4.0 and it also shows that how employees take it. It is all about the mind set of an employee how they want to take it (Valmohammadi, 2011). An employee should be ready mentally and physically to accept a change that occur in their working environment. This also portraits that machines and technologies will take the part 


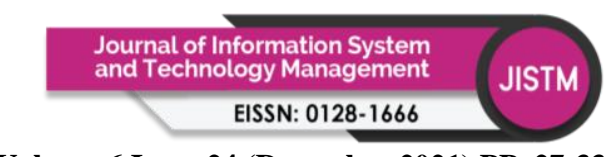

Volume 6 Issue 24 (December 2021) PP. 27-33 DOI: 10.35631/JISTM.624004

of employees. This might be also lead to reduce the opportunities for low-skilled workers simultaneously. The readiness of an employee for a change will be influenced by self-belief, appropriateness, management support and personal-valence. An employee needs support and should have self-belief to implement a change in organization (Shah et al., 2017).

\section{Independent Variables: Industry Revolution 4.0}

The first independent variable is the technology or Internet of Things. The Internet of Thing (IoT) and Industry Revolution 4.0 are related concept. Industry Revolution 4.0 is the concept where all the process held using technologies and less manpower (Shrouf et al., 2014). Industry Revolution 4.0 also can be said as robotic world where all the machines and robots connected using internet (Khan and Turowski, 2016). According to Wilkesmann (2018) Industry 4.0 is characterized as a thorough digitalization and linking of production processes, starting with the customer's order and progressing through the construction of manufacturing processes to downstream product services. As a result, in the context of Industry 4.0, considerations go beyond mere IT-assisted process optimization. In the other hand, there will be new world will be created in manufacturing industry through implementing Industry Revolution 4.0. This smart factory will give a huge impact to employees and the responsibilities will change to next level. Industrial Internet of Thing (IIoT) is more related and connected to manufacturing industries (Rojko, 2017).

Environment and consumers' main reasons to influence an organization and today world. In this competitive industries, everything run under technology where everything computerized and digitalized. From the early usage of mechanical systems to assist production processes to today's highly automated assembly lines, industry progress has been hastened by the discovery of new technologies in order to be responsive and flexible to today's dynamic market requirements and demands. The company is under pressure from the environment to adapt to the current circumstances (Lee et al., 2015). As mentioned by Business, (2017) the government has taken a number of steps to encourage the sector's reform. Incentives packages for robotics and factory automation equipment and related modules, automation capital allowance for enterprises undertaking automation, and plant modernization and upgrade facilitation are among them. This will increase the production and export. This will also increase the income of the country and increase the competitive advantage (Low et al., 2017).

Employee performance is a multifaceted concept, and on the most fundamental level, the process aspect of performance, that is, behavioural engagements, can be distinguished from an expected outcome (Vithessonthi, 2005). It is true that organization performance is affected by employee performance. If the employee's performance is not great the outcome will poor for the organization. To solve employee performance issues, effective leadership, communication, employee development, change tolerance, and organisational culture will be used (Khan and Turowski, 2016). Tools and technologies are the credentials and capabilities that an Industry 4.0 employee must possess in order to accomplish tasks in the most efficient way possible (Hecklau et al., 2016). The skills and qualifications of the new type of employee are the most important factors in personnel selection criteria in Industry 4.0 (Müller et al., 2018). Because of the wide range of tasks in Industry 4.0, many new and emerging skills will be required that may not have been taught in employees' previous education, and some of these former skills may become obsolete. Employees in Industry 4.0 must have both hard and soft skills, such as the capacity to combine job-specific know-how with IT skills, organisational and processual 


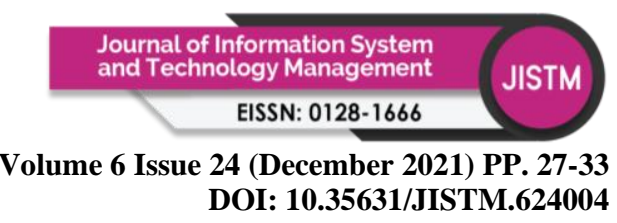

awareness, the capacity to engage with current interfaces, data security, flexibility to adapt to new roles and work situations, and ongoing interdisciplinary learning (Müller et al., 2018).

\section{Methodology}

The researcher in this study uses questionnaire to refer to any form of data collecting in which each respondent is asked to answer the same set of questions in a preset order. On a 5-point scale, 1 means strongly disagree, 2 means disagree, 3 means neutral, 4 means agree, and 5 means strongly agree. This rating scale in the questionnaire is to enable the respondent to indicate their answer. The researcher chooses three manufacturing companies which consist of 500 employees. The researcher choosed 3 manufacturing companies which were Apollo Food Industries, Halex Woolton Sdn Bhd and Southern Lion Sdn Bhd. The sample size using Morgan Sample Table (Krejcie and Morgan, 1970). The researcher decided to distribute the questionnaire to 333 respondents according to Morgan Sampling Table. The technique that used by the research that used by the research is random sampling. Simple random sampling and systematic random sampling are the two types of random sampling that can be used. This research employs systematic random sampling. Systematic random sampling is a type of probability sampling in which respondents are chosen from a vast population based on a fixed duration and a random beginning point. The sample will be divided by the desired sample size. For this research, the systematic sampling was used. The questionnaire will be given from 1 to 333 and the questionnaire will be distributed to the respondents following the order. Researcher uses primary data to collect information from the respondent such as questionnaire. The researcher uses the techniques of data collection where the respondent asked to fill in the questionnaire according to the rating scale. It will reveal their exact thoughts on the research. The questionnaire is divided into two sections, A and B. Meanwhile, section B is divided into four parts: A, B, C, and D. The data is analyzed using SPSS. The reliability and regression analysis are tested using SPSS.

\section{Finding}

For the descriptive analysis, the result shows that the majority of the respondents who completed the survey was female which $54.7 \%$ is and the rest of them are males with the percentage of $45.3 \%$. In term of age, the most of the respondent who answered the questionnaire 21-30 years old. There are 155 respondents $(46.6 \%)$. The second most is the respondents with middle age which is 31-40 years old. 136 of respondents are completed the survey which the percentage of them are $40.8 \%$. The least respondent who completed the survey are 41-50 years old. There are 42 of respondents (12.6\%).

A summary of the results based on the reliability analysis are presented in Table 1 . The aim of reliability analysis is to test the extent to which variable is consistent in what it should measure (Hair et al., 2006). In general, the closer the reliability coefficient gets to 1.00, the better the instruments are, whilst reliabilities less than 0.60 are deemed bad and those over 0.80 are deemed good (Sekaran, 2006). The results for all variables are good based on the reliability test. 
Volume 6 Issue 24 (December 2021) PP. 27-33 DOI: 10.35631/JISTM.624004

Table 1: Reliability Test

\begin{tabular}{cccc}
\hline $\begin{array}{c}\text { No of } \\
\text { Items }\end{array}$ & Study Variables & $\begin{array}{c}\text { Cronbach's } \\
\text { Alpha }\end{array}$ & Result \\
\hline 5 & Technology & 0.882 & Good \\
5 & $\begin{array}{c}\text { Changes in Consumers' } \\
\text { Behaviour and Environment }\end{array}$ & 0.849 & Good \\
5 & Employee Performance & 0.839 & Good \\
5 & Employee Readiness of & 0.881 & Good \\
\hline
\end{tabular}

Table 2 shows the full summarization of results from multiple regression analysis. The significant value of Independent Variable 1 which is technology shows $0.458(\mathrm{p}<0.05)$. The results indicate that the technology is not significant with the readiness of employee towards the implementation of Industry 4.0 because the $p$ value exceeds the alpha value which is 0.05 . Therefore, there is no relationship between technology and readiness of employee in implementing Industry 4.0. It also can be proven as we can see the current situation of Malaysia which is not ready technology vice. Furthermore, the significant value of Independent Variable 2 which is changes in consumers' behavior and environment is 0.000 . The value reflects that the variable has positive relationship with the DV which is readiness of employee in implementing Industry 4.0. This situation proves that consumers expecting more and becoming more modernized when comes to the industry. Lastly, the significant value ( $\mathrm{p}$-value $=0.000$ ) for employees' performance shows less than alpha $(\alpha=0.05)$. There is a considerable association between employee performance and employee readiness, it might be argued. The regression analysis clears that employees' performance is something essential to come up with the idea of Industry 4.0. Coefficient of determination explained the $62.6 \%$ variation in the readiness of employee is accounted for by the variations in the all variables involved (technology, changes in consumers' behavior and employees' performance). The coefficient of correlation value $(r=0.791)$ shows there is a strong positive relationship between all variables involved (technology, changes in consumers' behavior and employees' performance) and readiness of employee towards the implementation of Industry 4.0.

Table 2: Regression Analysis

\begin{tabular}{ccccc}
\hline Variables & $\begin{array}{c}\text { P- } \\
\text { Value }\end{array}$ & $\begin{array}{c}\text { Hypothesis } \\
\text { Result }\end{array}$ & R & $\begin{array}{c}\text { R- } \\
\text { Square }\end{array}$ \\
\hline $\begin{array}{c}\text { Technology } \\
\text { Changes in Consumer } \\
\text { Behaviour }\end{array}$ & 0.458 & $\begin{array}{c}\text { Rejected } \\
\text { Accepted }\end{array}$ & 0.791 & 0.626 \\
$\begin{array}{c}\text { Employee } \\
\text { Performance }\end{array}$ & 0.000 & Accepted & & \\
\hline
\end{tabular}

\section{Conclusion}

As the conclusion, the employees will understand the concept and importance of the implementation of Industry 4.0. Employees also will understand that Industry 4.0 will beneficial for them in the future. Furthermore, this researcher will get to know the current situation of Industry 4.0 in term of technology, changes in consumers' behavior and environment and also employees' performance. Employees will understand that technology is so much needed to implement Industry 4.0 and this will be the upcoming future. Employees also will understand that consumers' behavior are not stable and it will change according to the 


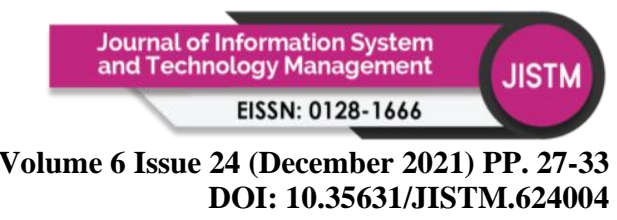

environmental change. They will put effort to change according to their consumers. Besides, employees will understand that their performance is significant to make a change to the industry in future. Employees will improve their performance with the help of their organization to implement the Industry 4.0. By enhancing the readiness and performance of employees, Malaysia can develop and achieve of Industry 4.0 in short period of time. According to the result, there are positive significant relationship between the independent variable (changes in consumers' behavior and environment and employees' performance) and dependent variable. It also shows that the independent variable gives huge impact to the dependent variable. The relationship between the technology and the readiness of employee towards the implementation Industry 4.0 is negative. Internet is the part of technology which is essential in development of Industry 4.0. The use of internet technology and big data analysis to accelerate manufacturing, services, and enterprises was critical to the advancement and development of Industry 4.0 (Lu, 2017).

\section{References}

Business, N. (2017) The Changing landscape of manufacturing sector.

Gobind Singh (2019) Malaysia serious on tech talent development agenda - Gobind, Bernama dot com.

Hair, J. F., Black, W. C., Babin, B. J. and Anderson, R. E. (2006) Multivariate Data Analysis (6th ed.), Analysis.

Hecklau, F., Galeitzke, M., Flachs, S. and Kohl, H. (2016) 'Holistic Approach for Human Resource Management in Industry 4.0', in Procedia CIRP.

Holt, D. T., Armenakis, A. A., Feild, H. S. and Harris, S. G. (2009) 'Readiness for organizational change: The systematic development of a scale', in Handbook of Military Industrial Engineering.

Howley, C. (2012) Readiness for Change. White Paper, ICF International.

Idris, R. (2019) 'Industrial Revolution 4.0: An Overview of Readiness and Potential Economic Effects in Malaysia from Millennial's Perspective', World Scientific News.

Khan, A. and Turowski, K. (2016) 'A perspective on industry 4.0: From challenges to opportunities in production systems', in IoTBD 2016 - Proceedings of the International Conference on Internet of Things and Big Data.

Krejcie, R. V. and Morgan, D. W. (1970) 'Determining Sample Size for Research Activities', Educational and Psychological Measurement.

Lee, J., Bagheri, B. and Kao, H. A. (2015) 'A Cyber-Physical Systems architecture for Industry 4.0-based manufacturing systems', Manufacturing Letters.

Low, M. K., Kasmuri, A. and Rubaneswaran, S. . (2017) 'Why should Malaysia Focus on Industry 4.0?', IM BizWatch.

Lu, Y. (2017) 'Industry 4.0: A survey on technologies, applications and open research issues', Journal of Industrial Information Integration.

Muhuri, P. K., Shukla, A. K. and Abraham, A. (2019) 'Industry 4.0: A bibliometric analysis and detailed overview', Engineering Applications of Artificial Intelligence.

Müller, J. M., Kiel, D. and Voigt, K. I. (2018) 'What drives the implementation of Industry 4.0? The role of opportunities and challenges in the context of sustainability', Sustainability (Switzerland).

Rojko, A. (2017) 'Industry 4.0 concept: Background and overview', International Journal of Interactive Mobile Technologies.

Sekaran, U. (2006) Research method of business: A skill-building approach, Writing. 
Volume 6 Issue 24 (December 2021) PP. 27-33 DOI: 10.35631/JISTM.624004

Shah, N., Irani, Z. and Sharif, A. M. (2017) 'Big data in an HR context: Exploring organizational change readiness, employee attitudes and behaviors', Journal of Business Research.

Shrouf, F., Ordieres, J. and Miragliotta, G. (2014) 'Smart factories in Industry 4.0: A review of the concept and of energy management approached in production based on the Internet of Things paradigm', in IEEE International Conference on Industrial Engineering and Engineering Management.

Valmohammadi, C. (2011) 'The impact of TQM implementation on the organizational performance of Iranian manufacturing SMEs', The TQM Journal, 23, pp. 496-509.

Vithessonthi, C. (2005) 'A Perception-Based View of the Employee: A Study of Employees' Reactions to Change', University of St. Gallen.

Wilkesmann, M. and Wilkesmann, U. (2018) 'Industry 4.0 - organizing routines or innovations?', VINE Journal of Information and Knowledge Management Systems.

Zaslavsky, A. and Jayaraman, P. P. (2015) 'Discovery in the Internet of Things: The Internet of Things (Ubiquity symposium)', Ubiquity. 